\title{
POSTERIOR RING ABSCESS OF METASTATIC ORIGIN IN BEHCET'S DISEASE*†
}

BY

\section{A, Feigenbaum and W. Kornblueth}

JERUSALEM

A POSTERIOR ring abscess of the cornea of non-traumatic origin seems to be a relatively rare condition. In the case described below this condition was a complication in a patient who was suffering from the so-called Behcet syndrome. Elsewhere the writers discussed this case along with a number of similar cases seen by them, under the title: "Behcet's disease as manifestation of a chronic septic condition connected with a constitutional disorder." The syndrome consists of the following main symptoms: aphthous stomatitis, general ulcers, uveitis (recurrent iridocyclitis with hypopyon), retinitis, optic neuritis and erythema nodosum-like skin eruptions on the lower extremities. It was emphasized by the writers that the syndrome in question represents a chronic septic condition produced by staphylococcus aureus and that this peculiar kind of sepsis (best characterized as sepsis lenta), may only occur in a constitutionally predisposed individual whose power of resistance is weakened, in most cases by latent tuberculosis.

As the corneal lesion in question was merely touched upen in the paper previously mentioned, which was primarily intended to elaborate the pathological background of the syndrome including the ocular disturbances involved, it seems to be worth while dwelling in somewhat greater detail on this complication.

R. R., male, aged 28 years, since October 23, 1944, under prolonged observation and treatment for recurrent uveitis and retinitis, again presented himself on February 13, 1945, complaining of unbearable pain in his left eye, caused by an exacerbation of the disease. An additional complication in the form of a posterior ring abscess had made its appearance. The patient was in a state of prostration. His temperature was $38.7^{\circ} \mathrm{C}$. On the scrotal skin two ulcers were present, their surface covered with purulent secretion.

Eye examination.-R.E.: Visual acuity amounted to 5/18. Cornea and aqueous humour were clear, the pupil was well dilated and in the retina small foci along the vessels accompanied by small haemorrhages were seen. L.E.: totally blind for two months, showed severe ciliary in jection, chemosis of the bulbar conjunctiva, oedema of the corneal epithelium and an annular infiltration of the posterior wall of the cornea, the ring being open in its lower part

\footnotetext{
- From the Ophthalmological Department, Rothschild Hadassah University Hospital, Jerusalem.
}

† Received for publication October 8, 1946. 
from 5 to 7 o'clock. A portion of the cornea approximately $2 \mathrm{~mm}$. wide was left clear between the infiltration and the limbus (Fig. 1). The anterior chamber was shallow and the aqueous humour cloudy with no visible hypopyon formation. The pupil, as far as could be seen, was partially dilated wherever not impeded by posterior synechiae. A complicated cataract was present and the ocular tension increased.

The day after admission to the hospital the annular infiltration advanced into the anterior, layers of the cornea, especially from the

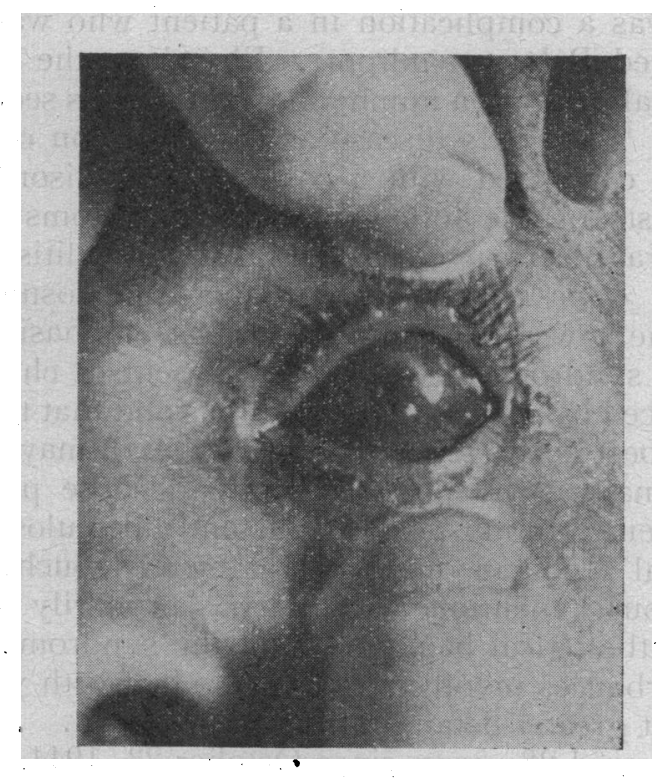

Fig. 1.

temporal side. In order to relieve the tension a paracentesis was performed. Culture of the aqueous humour showed a growth of staphylococcus aureus. The following day the annular infiltration did not change noticeably and ocular tension was still at the upper limit of normal. The chamber was reopened daily during the following days and the cultural findings of the aqueous were repeatedly positive. Staphylococcus aureus was also present in the two scrotal ulcers, while the blood culture proved sterile although temperature had risen up to $38.8^{\circ} \mathrm{C}$.

Treatment was started with sulfathiazole, 3 grams a day, for a week's time only when it had to be stopped because of general malaise and severe vomiting of the patient. In spite of this course with sulfathiazole the aqueous humour continued to show a growth of staphylococcus aureus'and the annular infiltration remained unchanged. 
On February 27, the patient complained of intense headaches and ran a temperature of $37.5^{\circ} \mathrm{C}$. Blood culture, taken after careful cleansing of the skin, over the cubital vein, with iodine and alcohol showed staphylococcus aureus."

On March 1, systemic penicillin treatment was commenced. Every three hours, day and night, 12,500 O.U. were administered intramuscularily for a fortnight until the total dose reached $1,000,000$ O.U. The second day after initiation of the penicillin injections the general condition of the patient improved, the infiltration of the left cornea lessened, the culture of the aqueous humour for the first time became sterile and remained so in the consecutive examinations. Even the scrotal ulcers, which in culture continued to show staphylococcus aureus, grew smaller and became flatter and cleaner. On the seventh and the eleventh day of the penicillin treatment the blood culture still showed staph. aureus. The local corneal process gradually cleared up while deep vascularisation indicated an incipient phthisis bulbi.

The main findings after a thorough general examination during the stay of the patient in the hospital were a systolic murmur over the whole region of the heart (endocarditis?) and an increase of the blood sedimentation rate (1h Linzenmeyer), while the blood picture did not show leucocytosis.

\section{Comment}

It is fair to assume that the condition under discussion is not as rare as would appear from the scarcity of reports. The not too numerous cases of posterior ring abscess of the cornea published in the literature roughly belong to two groups from the standpoint of aetiology, the traumatic and the metastatic. There is, however, no essential pathogenic difference between these two groups, of which the traumatic comprises the majority. The difference consists in the fact that in cases of metastatic origin the infective agent (deriving from a known or hidden focus) is brought into the inner eye by the vascular route, while in cases of traumatic origin it is introduced into the interior of the eye through the perforating wound. Once established intra-ocularly the microbes most probably act in a similar manner.

Severe acute pyogenic inflammations of the inner eye are regularly accompanied by a more or less pronounced lesion of the corneal endothelium and Descemet's membrane. This condition, frequently manifesting itself clinically in "wrinkling" of the latter membrane, brings about a breakdown of the posterior corneal barrier. Thus infective-toxic substances present in the anterior chamber will be able to enter more or less freely into the posterior lamellae of the cornea. Having entered the corneal tissue these 
toxins of bacterial origin may affect the whole posterior part of the cornea and finally the whole cornea, when there is no defensive power left which is the rule in severe cases of this kind. In other cases, however, where defensive forces are mobilized early enough (through the deep ciliary network surrounding the posterior lamellae) the damage to the cornea (varying in degree-up to necrosis) may remain confined to its centre. A defensive infiltration is initiated around the damaged cornea. The corneal periphery owing to its better nutrition remains clear and the infiltration gathers around the defenceless centre. This relatively rare condition appears clinically as a posterior ring abscess of the cornea.

Instead of a review of the literature $(a)$ the data contained in the table of Gifford \& Hunt (1929) are supplemented here, by adding those cases falling within the period of their report and not mentioned by them, and $(b)$ comprehensive data from 1929 up to date are compiled, with the exception of a small number of cases to which the present writers had no access. If the latter are not taken into account, thus a total of 42 cases are reported on in the literature, 18 of them belonging to the metastatic and 24 to the traumatic group.

To the columns appearing in Gifford and Hunt's table another one, namely " ocular tension" was added (see Table I) as the factor of increased tension may play a not inconsiderable part in the formation of a posterior ring abscess. Increased tension was mentioned in six out of 18 cases reviewed here, in only one normal tension was expressly stated, while no reference at all was made with regard to ocular tension in the remaining eleven cases.

In the literature dealing with the corneal lesion under discussion two main possibilities were considered which, in a mechanical way, might bring about a rise of tension in severe intra-ocular infection: (a) Swelling by massive inflammatory exudation into the vitreous (Fuchs, 1903) and (b) blocking of the network of the ligamentum pectinatum by bacteria (Stoelting, 1913) or by a sudden choroidal haemorrhage behind the angle of the anterior chamber (Seale, 1931). Besides the mechanical factors, however, increase of intra-ocular tension is certainly also due to vasomotor changes as well as to disturbances of the osmotic equilibrium : intra-ocular exudate rich in protein will effect retention of fluid and, in consequence, cause rise of tension.

In a state of increased intra-ocular tension the penetration of

- toxic substances into the posterior part of the cornea, as previously mentioned, will be greatly enhanced the pressure leading to a further diminution of the vitality of the corneal tissue. This damaging effect in conjunction with the main factor of the defensive annular infiltration arriving in time and in sufficient strength, may help in the formation of a posterior corneal ring abscess. 
TABLE I

Data from the Literature

\begin{tabular}{|c|c|c|c|c|c|}
\hline Name & $\begin{array}{l}\text { No. of } \\
\text { cases }\end{array}$ & $\begin{array}{l}\text { Causative } \\
\text { factor }\end{array}$ & $\begin{array}{l}\text { Observation and } \\
\text { bacteriology }\end{array}$ & $\begin{array}{l}\text { Ocular } \\
\text { tension }\end{array}$ & Result \\
\hline $\begin{array}{l}\text { Herrenheiser } \\
\text { (1893) }\end{array}$ & 1 & $\begin{array}{l}\text { Puerperal septi- } \\
\text { caemia }\end{array}$ & - & $?$ & - \\
\hline $\begin{array}{l}{ }^{*} \text { Wintersteiner } \\
(1903)\end{array}$ & 1 & $\begin{array}{l}\text { Puerperal septi- } \\
\text { caemia }\end{array}$ & - & ? & - \\
\hline Stoewer (1907) & 1 & Injury & $\begin{array}{l}\text { Culture from corneal } \\
\text { ulcer and from } \\
\text { aqueous humour: } \\
\text { bacilli of the family } \\
\text { of bac. proteus }\end{array}$ & Increased & Enucleation \\
\hline Mizuo (1910) & 1 & Bubonic plague & No bacteriologic work & $?$ & Perforation \\
\hline - & 1 & Babonic plague & No bacteriologic work & ? & Death \\
\hline - & 1 & Bubonic plague & $\begin{array}{l}\text { In the suprachoroidal } \\
\text { space some bacilli } \\
\text { similar to involution } \\
\text { forms of plague } \\
\text { bacilli }\end{array}$ & Increased & Enucleation \\
\hline - & 1 & Bubonic plague & $\begin{array}{l}\text { Plague bacilli mainly } \\
\text { in aqueous humour }\end{array}$ & $?$ & $\begin{array}{l}\text { Enucleation } \\
\text { death }\end{array}$ \\
\hline King $(1925) \ldots$ & 1 & $?$ & $\begin{array}{l}\text { Smear and culture of } \\
\text { secretion pneumo- } \\
\text { cocci }\end{array}$ & Increased & Evisceration \\
\hline $\begin{array}{l}\text { Gifford and } \\
\text { Hunt }(1929)\end{array}$ & 1 & Injury & $\begin{array}{l}\text { Smears and cultures } \\
\text { from cut surface of } \\
\text { cornea and vitreous. } \\
\text { Bac. subtilis }\end{array}$ & ? & Evisceration \\
\hline - & 1 & Injury & $\begin{array}{l}\text { Smears and cultures } \\
\text { from the cornea and } \\
\text { vitre ous. Bac. } \\
\text { subtilis: }\end{array}$ & $?$ & Evisceration \\
\hline- & 1 & Injury & $\begin{array}{l}\text { Smears and cultures } \\
\text { from correa and } \\
\text { vitreous probably } \\
\text { Bac. subtilis }\end{array}$ & $?$ & Evisceration \\
\hline - & 1 & Injury & $\begin{array}{l}\text { Bacteriologie work not } \\
\text { done. In } 2 \text { rabbits } \\
\text { successful inocula- } \\
\text { tion of vitreous }\end{array}$ & $?$ & Evisceration \\
\hline Seale $(1931) \ldots$ & 1 & $\begin{array}{l}\text { Diabetes, car- } \\
\text { buneles }\end{array}$ & $\begin{array}{l}\text { Bacteriologic work } \\
\text { not reported }\end{array}$ & Increased & Death \\
\hline Barkan (1933) & 1 & $\begin{array}{l}\text { Agranulocytic } \\
\text { angina }\end{array}$ & Blood culture negative & $\begin{array}{l}\text { Normal (in } \\
\text { the late } \\
\text { stage) }\end{array}$ & $\begin{array}{r}\text { Perforation } \\
\text { of cornea }\end{array}$ \\
\hline
\end{tabular}

* This case is included in Gifford and Hunt's table among Fuchs' ten cases 
TABLE I-contiuued

Data from the Literature

\begin{tabular}{|c|c|c|c|c|c|}
\hline Name & $\begin{array}{l}\text { No. of } \\
\text { cases }\end{array}$ & $\begin{array}{l}\text { Cansative } \\
\text { factor }\end{array}$ & $\begin{array}{c}\text { Observation and } \\
\text { bacteriology }\end{array}$ & $\begin{array}{l}\text { Ocular } \\
\text { tension }\end{array}$ & Result \\
\hline $\begin{array}{l}\text { Herrmann } \\
\text { (1934) }\end{array}$ & 1 & $\begin{array}{l}\text { After exacerba- } \\
\text { tion of trach- } \\
\text { oma and pan- } \\
\text { nus, s mall } \\
\text { corneal ulcer }\end{array}$ & $\begin{array}{l}\text { Bacteriologic finding } \\
\text { negative }\end{array}$ & $?$ & $\begin{array}{l}\text { Remaining } \\
\begin{array}{l}1 / 10 \text { of } \\
\text { vision }\end{array}\end{array}$ \\
\hline $\begin{array}{r}\text { Grancini } \\
\text { (1937) }\end{array}$ & 1 & $\begin{array}{r}\text { Streptococcal } \\
\text { septicaemia }\end{array}$ & Streptococci in blood & $?$ & $\begin{array}{l}\text { Perforation } \\
\text { of cornea, } \\
\text { death }\end{array}$ \\
\hline Tooker (1939) & 1 & $\begin{array}{l}\text { Staphylococcal } \\
\text { septicaemia }\end{array}$ & Staphylococci in blood & Increased & $\begin{array}{l}\text { Phthisis } \\
\text { bulbi }\end{array}$ \\
\hline $\begin{array}{c}\text { Feigenbaum \& } \\
\text { Kornblueth } \\
\text { (1946) }\end{array}$ & 1 & Behcet's disease & $\begin{array}{l}\text { Staphylococci in blood } \\
\text { and aqueous humour }\end{array}$ & Increased & $\begin{array}{l}\text { Phthisis } \\
\text { bulbi }\end{array}$ \\
\hline
\end{tabular}

\section{Summary}

A case of posterior ring abscess of the cornea is described for the first time in Behcet's disease, a chronic septic condition caused by staphylococcus aureus in a constitutionally predisposed individual.

The rôle played by increased intra-ocular tension is stressed which, along with other known aetiological factors, may produce a posterior ring abscess of the cornea.

The cases reported on in the literature are compiled in a table, which is a supplementation of Gifford and Hunt's table published in 1929 and its continuation up to date. .

\section{REFERENCES}

BARKAN, H.-Amer. Jl. Ophthal., Vol. XVI, pp. 406-408, 1933.

Feigenbaum, A. and Kornblueth, W.-Acta Medica Oriental., vol. V, pp. 139-151, 1946.

Fuchs, E.-Graefe's Arch. f. Ophthal., Vol. LVI, pp. 1-31, 1903.

GIFFORD, S. R. and HUNT, C. E.-Arch. Ophthal., Vol. I, pp. 494-500, 1929.

Grancini, E.-Boll. d'Ocul., Vol. XVI, pp. 742-752, 1937.

HERRENHEISER, J.-Prager Zeitschr. f. Heilk., Vol: XIV, 1893.

HerRMANN, P.-Arch. d'Ophtal., Vol. LI, p. 671, 1934.

KING, C. L.-Amer. Jl. Ophthal., Vol. VIII, pp. 723-724, 1925.

MizUo, G.-Arch.f. A ugenheilk., Vol. LXV, pp. 1-41, 1910.

SEALE, E. A.-Brit. Jl. Ophthal., Vol.XV, pp. 514-515, 1931.

Stoelting, B.-Klin. Monatsbl. f. Augenheilk., Vol. LI, pp. 5-19, 1913.

Stoewer, P.-Klin. Monatsbl. f. Augenheilk., Vol. XLV, pp. 372-374, 1907.

TOOKER, C. W.-Amer. Jl. Ophthal., Vol. XXII, pp. 526-535, 1939. 